\title{
膀胱癌に対する光力学診断およびその応用 一蛍光スペクトラム診断・光力学診断補助下経尿道的膀胱腫瘍切除術一
}

高知大学医学部泌尿器科学教室 ${ }^{1}$, 高知大学医学部病理学教室 ${ }^{2)}$

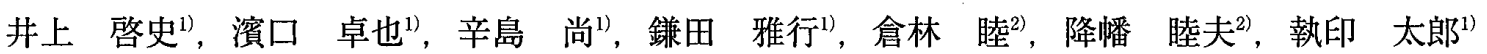

(目的) 膀胼癌に対する5-アミルレプリン酸 (5-ALA) の膀胱内注入による光力学診断 (PDD)，その技術応用である蛍光スペクトラム解析による定量的診断およ びPDD 補助による経尿道的膀肤腫啺切除術 (TURBT) の有用性の検討. (対象と方法) 膀脱癌 51 例において 5-ALA 溶液 (5-ALA 1.5g) 膀肤内注入による PDD

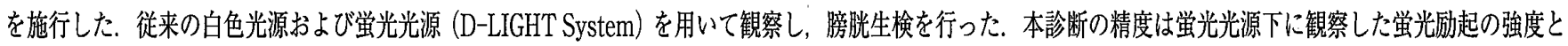

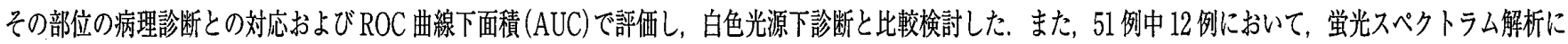
よる定量的診断を行った，分光器内蔵型紫色半導体レーザー装置 (Violet Laser Diode-M1)を用いて，各部位での5-ALAによる蛍光強度 (R:636nm) と自家蛍 光強度 $(\mathrm{G}: 505 \mathrm{~nm})$ の比 $(\mathrm{R} / \mathrm{G}$ 比) を定量し，視覚的PDD の結果と比較梌討したささらに, 51 例中 35 例において, PDD補助下 TURBT を施行し，膀胱内再発 に関して検討した, 従来の TURBT の要領で白色光源下にて隆起病变を切除後, 蛍光光源下にて切除䩮部に蛍光㢦起部位が存在した場合にはその部位も切除した. ただし，蛍光励起かつ病理学的に癌が磪認された径 $3 \mathrm{~cm}$ 以下の平坦病変に対しては, 術後 6 週間以後に蛍光光源下にて 2 次的に切除した. (結果) 全 420 生検検体 の内, 上皮内癌斿よび異形成を含む 147 検体が病理学的に悪性と診断された. 感度 $92.5 \%$, 特異度 $60.1 \%$ で, 本診断の AUC が白色光源下診断の AUCを有意に上 回った．また，営光スペクトラム解析による全 114 検体にお计る R/G 比の cut-off 值 0.962 をとにした定量的診断の精度は，感度 $95.5 \%$, 特異度 $70.7 \%$ と視觉 的PDD と比較して改善したが, AUC は有意な差は認めなかった. PDD 補助下 TURBT 施行症例の内, 隆起病変および边縁部を 1 次的に切除した症例は 29 例で,

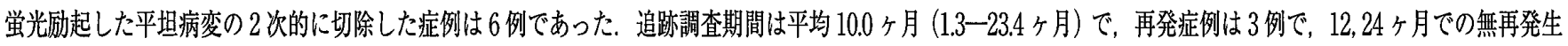
存率はいずれも 89.5\% であった，診断・治療を通しての副作用は軽度の膀胱刺激症状のみで，全身的な副作用は認めなかった（結論) 膀脱癌において5-ALA

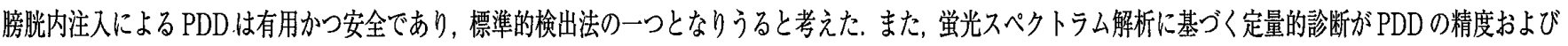
再現性の向上に寄与する可能性が示唆された，さらに，PDD補助下 TURBT は䏽肬内再発を制御しうる可能性が示唆された。

\section{S7-3}

\section{膀胱癌蛍光膀胱鏡検査における画像解析の意義}

山口大学大学院医学系研究科泌尿器科学分野

松山 豪泰, 原 智彦, 赤尾 淳平, 江口 賢, 長尾一公, 大見 千英高, 坂野 滋, 内藤 克輔

【背景、目的】近年欧米でプロトポルフィリン IX (PPIX) の前駆体である 5-aminolevulinic acid (以下 5-ALA)を膀胱内に注入し、 励起光下にポルフイリンの発する赤色の蛍光を観察し CIS を発見する蛍光膀胱鏡検查がおこなわれている。しかし同法は肉眼で 色調の変化を検索するため感度は高いものの特異度が低く、偽陽性が多いことが問題となっている。そこで本研究の目的は癌部と 非癌部をデジタル信号下の色調差を解析することにより、特異度を向上させることである。対象症例および方法】対象は CIS が疑 われた膀胱癌患者 16 例（初発/再発：7/9, 平均年齢：68.4 歳)である。方法は 1) 蛍光膀胱鏡施行 2 時間前に 3\% 5-ALA 溶液 (1.5 $\mathrm{g} / 50 \mathrm{ml}$ リン酸緩衝液) を膀腅内に注入 2) D-light 光源装置 (励起波長 380-440nm, Karl Storz 社)をもちいて膀腅内を観察、画 像をデジタル処理後記録 3）記録部位の粘膜を生検 4）画像解析ソフト（LuminaVision）を用いて、解析領域濃度断面を赤青緑 の 3 原色に分け、赤 (ポルフィリンの特異的波長由来) を青 (背景の非特異的波長由来) で除した $\mathrm{R} / \mathrm{B}$ 比を計算した。結果】薬剤 平均貯留時間は 116 分 (30-157 分)、平均観察時間は 22.3 分であった。副作用は 2 例に貯留時の膀胱刺激症状 (一過性) をみとめ た。計 77 検体 (蛍光部：56, 非蛍光部：21)の病理組織所見は癌：42(全例移行上皮癌, pTis:20, pTa:11, pT1:10, pT2:1), dysplasia :7, 正常粘膜 : 28 であった。肉眼所見および蛍光膀胱鏡による癌診断の感度はそれぞれ $73.8 \%, 90.5 \%$ 、特異度は $73.5 \%$, $47.1 \%$ であり、虽光膀胱鏡検查における偽陽性は $52.9 \%$ と高值であった。癌部、mild-moderate dysplasia, 正常粘膜の平均 R/B 比はそれぞれ 2.11 (95\%CI:1.76-2.45)，1.19（95\%CI:0.29-2.08)，0.60（95\%CI:0.15-1.05）であり、有意差を認めた。そこで R/B 比のカットオフを 1.1 とした時、感度 $78.1 \%$, 特異度 : $80 \%$ となり偽陽性は $20 \%$ に低下した。また肉眼的に異常を認めず癌が 発見された 11 検体中 7 検体 $(63.6 \%)$ に蛍光を認めた。結語】蛍光膀胱鏡検査は肉眼的に異常を認めない癌病変の診断に有用な検 查であったが為陽性を多く認めた。偽陽性を判別するために画像解析による R/B 比計測の有用性が示唆された。 